\title{
An in vitro study on the effects of the combination of salinomycin with cisplatin on human gastric cancer cells
}

\author{
ZUWEN ZHANG ${ }^{*}$, JUMEI ZHAO*, QIUXIA PANG ${ }^{*}$, AIHONG WANG, MEINI CHEN and XIAOLI WEI \\ Medical College, Yan'an University, Yanan, Shaanxi 716000, P.R. China
}

Received March 3, 2016; Accepted February 20, 2017

DOI: $10.3892 / \mathrm{mmr} .2017 .6731$

\begin{abstract}
The present study aimed to investigate the anticancer effects of cisplatin (DDP) combined with salinomycin (SAL) on the gastric cancer cell line SGC-7901, as well as to explore the mechanisms underlying their actions. An MTT assay was used to evaluate the inhibitory effects of SAL, DDP and their combination on gastric cancer cell proliferation. Morphological alterations of cancer cells following treatment were observed under an inverted phase-contrast microscope and a fluorescence microscope. Cell cycle progression and apoptosis were analyzed using flow cytometry. The expression of nuclear factor (NF)- $\mathrm{B}$ p65 and Fas protein ligand (L) in cancer cells was assessed using immunocytochemistry. The present results demonstrated that the combination of SAL and DDP significantly inhibited the proliferation $(\mathrm{P}<0.05)$ and altered the morphological characteristics of SGC-7901 cells, thus suggesting that SAL may enhance the susceptibility of gastric cancer cells to DDP. In addition, treatment with a combination of SAL and DDP resulted in S phase-arrest and increased the apoptotic rate of SGC-7901 cells. Furthermore, marked FasL upregulation and NF- $\mathrm{B}$ p65 downregulation were observed in cancer cells treated with the combination of SAL and DDP. The results of the present study demonstrated that the combination of SAL and DDP induced the apoptosis of human gastric cancer cells, and suggested that the underlying mechanism may involve the upregulation of FasL and downregulation of NF- $\mathrm{B}$ p 65 .
\end{abstract}

\section{Introduction}

Gastric carcinoma is one of the most common gastrointestinal malignancies worldwide, and is developed mainly in gastric endothelial tissue. It is characterized by high incidence and

Correspondence to: Professor Jumei Zhao, Medical College, Yan'an University, 580 Shengdi Road, Yanan, Shaanxi 716000, P.R. China

E-mail: jmz2003.stu@163.com

*Contributed equally

Key words: salinomycin, gastric cancer, cisplatin, NF-кB p65, Fas mortality rates, and it was the second most common type of cancer in China in 2009, thus posing a serious threat for global health (1). Cisplatin (DDP) has significant anticancer effects on gastric carcinoma; however, its use is limited due to its severe side effects (2). In addition, DDP has been associated with the development of drug resistance, which may result in failure of anticancer treatment (3-5). Therefore, the development of novel therapeutic strategies, as well as novel drug combinations, characterized by high efficiency and low toxicity, is of great clinical significance for the treatment of patients with gastric cancer.

Several polyether ionophores have demonstrated anticancer activity against the proliferation of various cell types, such as leukemia, colon carcinoma and prostate cancer cells, and cancer stem cells, including tumors that exhibit multi-drug resistance (6). Salinomycin (SAL) is a carboxyl polyether, first extracted from Streptomyces albus in 1974 (7). Due to its cation-neutralizing properties it can potently inhibit the growth of most Gram-positive bacteria and various Coccidia (8-10). Gupta et al reported that the inhibitory effects of SAL on breast cancer stem cell proliferation were $\sim 100$ times more potent than the chemotherapeutic agent paclitaxel (11). Previous studies have demonstrated that SAL exhibited anticancer effects in various types of cancer and may have potential as a novel anticancer agent $(8,12-18)$.

It has previously been reported that nuclear factor $(\mathrm{NF})-\kappa \mathrm{B}$ may be implicated in the development of tumor drug resistance (19), whereas SAL was demonstrated to effectively inhibit the proliferation of cancer stem cells with high drug resistance (20-21). Therefore, it may be hypothesized that SAL can inhibit the activation of $N F-\kappa B$, and thus increase the susceptibility of gastric cancer cells to DDP. In the present study, the anticancer effects of SAL, DDP and their combination were evaluated in the SGC-7901 gastric cancer cell line. In addition, the mechanisms underlying their actions in the induction of cancer cell apoptosis were investigated.

\section{Materials and methods}

Reagents. SAL was purchased from Shunbo Biological Technology and Engineering Co., Ltd. (Shanghai, China). DDP was obtained from Jiangsu Hansoh Pharmaceutical Group Co., Ltd. (Jiangsu, China). MTT solution was purchased from Merck KGaA (Darmstadt, Germany). RPMI-1640 medium was purchased from Thermo Fisher Scientific, Inc. (Waltham, 
MA, USA). Fetal bovine serum (FBS) was purchased from Hangzhou Sijiqing Biological Engineering Materials Co., Ltd. (Hangzhou, China). Propidium iodide (PI) was purchased from Merck KGaA. Acridine orange (AO) was obtained from Amresco, LLC (Solon, OH, USA). Annexin V-fluorescein isothiocyanate (FITC)/PI apoptosis detection kit was purchased from BD Biosciences (Franklin Lakes, NJ, USA). The rabbit anti-human NF- $\mathrm{B}$ p65 polyclonal antibody (cat. no. A00224) was obtained from GenScript (Nanjing) Co., Ltd. (Nanjing, China). The 3,3'-diaminobenzidine (DAB) color developing kit, rabbit anti-human Fas protein ligand (L) polyclonal antibody (cat. no. BA0049) and biotin-labeled secondary antibody (cat. no. BA1003) were purchased from Wuhan Boster Biological Technology, Ltd. (Wuhan, China).

Cell culture. The SGC-7901 human gastric cancer cell line was purchased from Digestion Research Center of Xi'an Jiaotong University Health Science Center (Xi'an, China). Cells were cultured in RPMI-1640 medium, supplemented with $10 \% \mathrm{FBS}, 100 \mathrm{U} / \mathrm{ml}$ penicillin and $100 \mathrm{U} / \mathrm{ml}$ streptomycin and maintained in a humidified $5 \% \mathrm{CO}_{2}$ atmosphere at $37^{\circ} \mathrm{C}$.

MTT assay. SGC-7901 cells at the logarithmic growth phase were seeded in 96-well plates at a density of $1 \times 10^{4}$ cells/well, and incubated at $37^{\circ} \mathrm{C}$ overnight to form a monolayer. Cells were divided into the following four groups: SAL group, where cells were treated with 4,8 and $16 \mu \mathrm{mol} / 1 \mathrm{SAL}$ (dissolved in ethanol); DDP group, where cells were treated with $6 \mu \mathrm{mol} / 1$ DDP (dissolved in normal saline); combination group, where cells were treated with SAL (4, 8 and $16 \mu \mathrm{mol} / \mathrm{l})$ and DDP (6 $\mu \mathrm{mol} / \mathrm{l})$; and control group, where cells did not receive drug treatment. Experiments were repeated 5 times for each group. Cells were incubated in a $95 \%$ humidified atmosphere at $37^{\circ} \mathrm{C}$ and $5 \% \mathrm{CO}_{2}$ for 24, 48 and $72 \mathrm{~h}$. Following incubation, MTT solution $(20 \mu \mathrm{l})$ was added and cells were incubated at $37^{\circ} \mathrm{C}$ for an additional $4 \mathrm{~h}$. Subsequently, the supernatants were removed and the crystals were dissolved with $150 \mu \mathrm{l}$ DMSO. The absorbance at $490 \mathrm{~nm}$ was measured to assess cellular proliferation. Results were averaged from three independent measurements.

Cellular morphology. SGC-7901 cells were seeded in a 6-well plate at a density of $2 \times 10^{5}$ cells/well. Following incubation for $24 \mathrm{~h}$, drugs were added. The cells were divided into four groups: SAL group $(8 \mu \mathrm{mol} / 1)$, DDP group $(6 \mu \mathrm{mol} / 1)$, combination group [SAL $(8 \mu \mathrm{mol} / \mathrm{l})$ and DDP $(6 \mu \mathrm{mol} / \mathrm{l})]$ and control group. Following incubation for $48 \mathrm{~h}$, cellular morphology was observed under an inverted phase-contrast microscope (Nikon Corporation, Tokyo, Japan). All experiments were repeated three times.

In another set of experiments, following drug treatment for $48 \mathrm{~h}$ as aforementioned, cells were washed twice with PBS and fixed with $75 \%$ ice cold ethanol for $2 \mathrm{~h}$ at $-20^{\circ} \mathrm{C}$. Subsequently, PI $(50 \mu \mathrm{g} / \mathrm{l})$ was added and incubated at $4^{\circ} \mathrm{C}$ for $30 \mathrm{~min}$ in the dark; after which, $\mathrm{AO}(50 \mu \mathrm{g} / \mathrm{ml})$ was added and incubated at $4^{\circ} \mathrm{C}$ for $10 \mathrm{~min}$ in the dark. Cellular morphology was observed under a fluorescence microscope (Nikon Corporation). All experiments were repeated three times.

Flow cytometry. SGC-7901 cells were seeded in a 6-well plate at a density of $2 \times 10^{5}$ cells/well. Following incubation for $24 \mathrm{~h}$, fresh medium containing $0.5 \%$ FBS was added and cells were cultured for an additional $24 \mathrm{~h}$ to synchronize. Cells received treatment with different drugs as aforementioned and were incubated for $48 \mathrm{~h}$. Subsequently, cells were digested with trypsin, collected and fixed with $75 \%$ ice-cold ethanol for $2 \mathrm{~h}$ at $-20^{\circ} \mathrm{C}$. The cell suspension was centrifuged at $350 \mathrm{x} \mathrm{g}$ for $5 \mathrm{~min}$ at room temperature and the supernatant was discarded. Following washing with PBS, cells were incubated with RNase $(20 \mu \mathrm{g} / \mathrm{l})$ at $37^{\circ} \mathrm{C}$ for $30 \mathrm{~min}$. For cell cycle analysis, cells were fixed with $75 \%$ ice-cold ethanol for $2 \mathrm{~h}$ at $-20^{\circ} \mathrm{C}$ and were then stained with PI $(50 \mu \mathrm{g} / \mathrm{l})$ for $30 \mathrm{~min}$ at $4^{\circ} \mathrm{C}$. Cell cycle analysis was performed using a Sysmex CyFlow ${ }^{\circledR}$ Cube 8 flow cytometer (Sysmex Europe GmbH, Norderstedt, Germany) and data were analyzed using FCS Express Application V3 software (De Novo Software, Glendale, CA, US).

To evaluate cellular apoptosis, SGC-7901 cells were prepared as aforementioned in the Cellular morphology subsection. Following drug treatment for 48 h, cells were collected, washed twice with PBS, transferred to Eppendorf tubes and stained with Annexin V-FITC and PI for $10 \mathrm{~min}$ at $4^{\circ} \mathrm{C}$, according to the manufacturer's protocol. The apoptotic rate was assessed in all experimental groups using a Sysmex CyFlow ${ }^{\circledR}$ Cube 8 flow cytometer (Sysmex Europe $\mathrm{GmbH}$ ) and data were analyzed using FCS Express Application V3 software (De Novo Software).

Immunocytochemistry. SGC-7901 cells were prepared as aforementioned in the Cellular morphology subsection. Following incubation for $48 \mathrm{~h}$, cells were washed with PBS three times and fixed with $4 \%$ paraformaldehyde for $20 \mathrm{~min}$ at room temperature. After air-drying, cells were fixed to glass slides using neutral gum and permeabilized with $0.3 \%$ Triton X-100 for $15 \mathrm{~min}$ at room temperature. Following a wash with PBS, cells were incubated with trypsin at $37^{\circ} \mathrm{C}$ for $30 \mathrm{~min}$ followed by $3 \% \mathrm{H}_{2} \mathrm{O}_{2}$ for $20 \mathrm{~min}$ at $37^{\circ} \mathrm{C}$, the cells were then blocked with goat serum (Wuhan Boster Biological Technology, Ltd.) for $30 \mathrm{~min}$ at $37^{\circ} \mathrm{C}$. Subsequently, cells were incubated with anti-NF- $\kappa$ B p65 (dilution 1:100) and anti-FasL primary antibodies (dilution $1: 100$ ) at $4^{\circ} \mathrm{C}$ overnight. Following a wash with PBS, cells were incubated with biotin-labeled secondary antibodies (dilution 1:500) (cat. no. BA1003; Wuhan Boster Biological Technology, Ltd.) for $2 \mathrm{~h}$ at room temperature, and then stained with DAB in the dark for $5 \mathrm{~min}$. The staining was monitored under a microscope and the slides were washed with water to terminate the reaction. Hematoxylin was used for counter-staining at room temperature for $5 \mathrm{~min}$. Hydrochloric acid alcohol $(0.1 \%)$ was used to differentiate the staining, and sections were dehydrated with alcohol, cleared with xylene and sealed with neutral gum. Photomicrographs were captured with a Nikon E600 microscope (Nikon Corporation, Tokyo, Japan).

Statistical analysis. The statistical significance of the difference between groups was assessed by one-way analysis of variance, followed by a post hoc least significant difference test. All experiments were repeated three times. Data are expressed as the mean \pm standard deviation. $\mathrm{P}<0.05$ was considered to indicate a statistically significant difference. The analysis was performed using IBM SPSS software version 22.0 (IBM SPSS, Armonk, NY, USA). 
Table I. Inhibitory rate of SAL and DDP on SGC-7901 cellular proliferation.

\begin{tabular}{|c|c|c|c|}
\hline \multirow[b]{2}{*}{ Group } & \multicolumn{3}{|c|}{ Inhibitory rate (\%) } \\
\hline & $24 \mathrm{~h}$ & $48 \mathrm{~h}$ & $72 \mathrm{~h}$ \\
\hline Control & 0 & 0 & 0 \\
\hline $\mathrm{DDP}(6 \mu \mathrm{mol} / \mathrm{l})$ & $15.52 \pm 0.75^{\mathrm{a}}$ & $27.38 \pm 0.63^{\mathrm{a}}$ & $40.99 \pm 1.11^{\mathrm{a}}$ \\
\hline $\mathrm{SAL}(4 \mu \mathrm{mol} / \mathrm{l})$ & $17.63 \pm 1.48^{\mathrm{a}}$ & $31.56 \pm 1.34^{\mathrm{a}}$ & $42.48 \pm 1.24^{\mathrm{a}}$ \\
\hline $\mathrm{SAL}(8 \mu \mathrm{mol} / \mathrm{l})$ & $26.47 \pm 1.30^{\mathrm{a}}$ & $46.64 \pm 1.03^{\mathrm{a}}$ & $55.18 \pm 0.80^{\mathrm{a}}$ \\
\hline $\mathrm{SAL}(16 \mu \mathrm{mol} / \mathrm{l})$ & $33.75 \pm 1.46^{\mathrm{a}}$ & $58.23 \pm 1.09^{\mathrm{a}}$ & $70.91 \pm 1.82^{\mathrm{a}}$ \\
\hline $\mathrm{SAL}(4 \mu \mathrm{mol} / \mathrm{l})+\mathrm{DDP}(6 \mu \mathrm{mol} / \mathrm{l})$ & $25.63 \pm 1.03^{\mathrm{a}, \mathrm{b}}$ & $41.73 \pm 1.35^{\mathrm{a}, \mathrm{b}}$ & $51.74 \pm 1.02^{\mathrm{a}, \mathrm{b}}$ \\
\hline $\mathrm{SAL}(8 \mu \mathrm{mol} / \mathrm{l})+\mathrm{DDP}(6 \mu \mathrm{mol} / \mathrm{l})$ & $38.54 \pm 1.14^{\mathrm{a}, \mathrm{b}}$ & $57.36 \pm 1.17^{\mathrm{a}, \mathrm{b}}$ & $69.98 \pm 1.08^{\mathrm{a}, \mathrm{b}}$ \\
\hline $\mathrm{SAL}(16 \mu \mathrm{mol} / \mathrm{l})+\mathrm{DDP}(6 \mu \mathrm{mol} / \mathrm{l})$ & $57.44 \pm 0.73^{\mathrm{a}, \mathrm{b}}$ & $72.35 \pm 0.86^{\mathrm{a}, \mathrm{b}}$ & $89.76 \pm 1.25^{\mathrm{a}, \mathrm{b}}$ \\
\hline
\end{tabular}

${ }^{\text {a }}<0.05$ compared with the control group at each time point; ${ }^{b} \mathrm{P}<0.05$ compared with the SAL or DDP group at each time point. Data are expressed as the mean \pm standard deviation of three independent measurements. DDP, cisplatin; SAL, salinomycin.

A

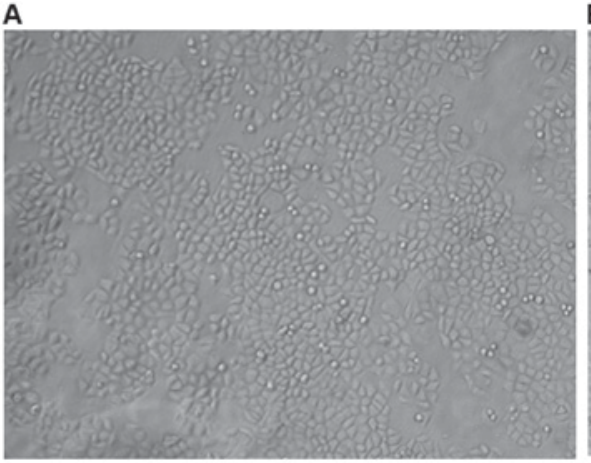

C

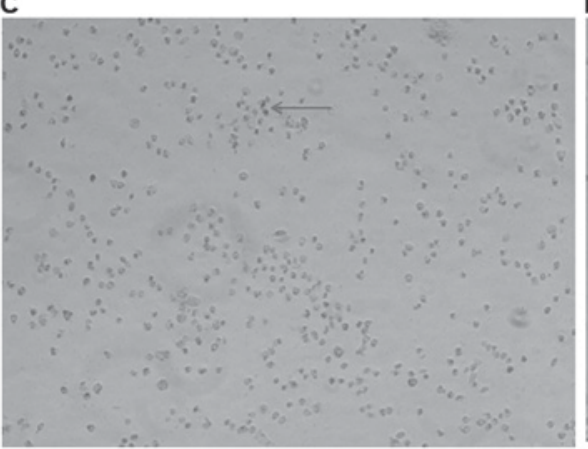

B

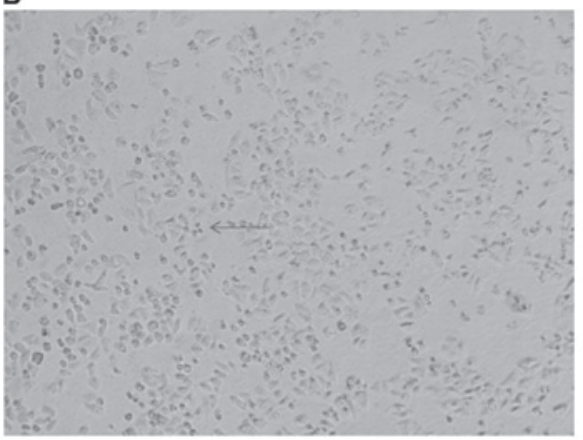

D

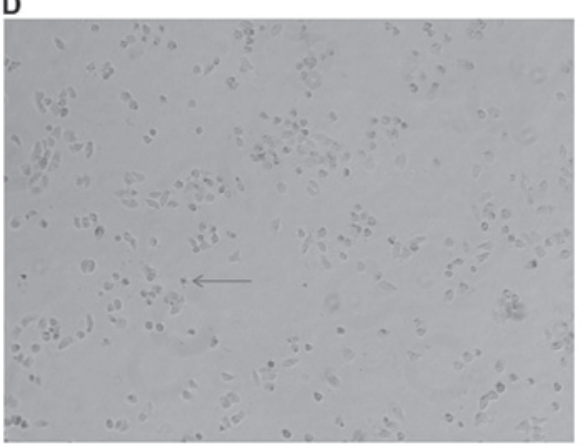

Figure 1. Morphological alterations of SGC-7901 cells following treatment with SAL, DDP or a combination of SAL and DDP. (A) Control cells received no treatment. (B) Cells were treated with $6 \mu \mathrm{mol} / 1$ DDP for $48 \mathrm{~h}$. (C) Cells were treated with $8 \mu$ mol/1 SAL for $48 \mathrm{~h}$. (D) Cells were treated with a combination of $8 \mu \mathrm{mol} / \mathrm{SAL}$ and $6 \mu \mathrm{mol} / 1 \mathrm{DDP}$ for $48 \mathrm{~h}$. Arrows indicate shrinkage of nuclear membranes. Magnification, x100. SAL, salinomycin; DDP, cisplatin.

\section{Results}

Effects of SAL and DDP on SGC-7901 proliferation. To assess the inhibitory effects of SAL and DDP alone, as well as their combination, on cellular proliferation, the MTT assay was performed. Results revealed that SAL and DDP inhibited the proliferation of SGC-7901 cells, and their inhibitory rate increased with the concentration used and the incubation time (Table I). The combination of SAL (4, 8 and $16 \mu \mathrm{mol} / \mathrm{l})$ and DDP $(6 \mu \mathrm{mol} / \mathrm{l})$ exerted a significant inhibitory effect on cellular proliferation following 24, 48 and $72 \mathrm{~h}$ of incubation, compared with the control, DDP alone and SAL alone groups
$(\mathrm{P}<0.05)$. These results suggested that $\mathrm{SAL}$ may be able to enhance the susceptibility of SGC-7901 cells to DDP.

Alterations in cellular morphology following treatment with SAL and DDP. To assess the effects of SAL and DDP alone, as well as their combination, on cellular morphology, the shapes of SGC-7901 cells were observed following treatment. In the control group, SGC-7901 cells grew adherently, connected closely and tightly, and were characterized by a full cytoplasm and a polygonal or spindle shape (Fig. 1A). Following treatment with SAL or DDP for $48 \mathrm{~h}$, cells appeared to shrink, gaps between cells became larger, cell-cell connections 
disappeared, nuclear membranes started to shrink and cellular volume decreased (Fig. 1B and C). When the combination of SAL and DDP was applied, cellular volumes appeared to be further reduced compared with the DDP alone and SAL alone groups, and cell numbers also decreased (Fig. 1D).

To determine the effects of SAL or DDP alone, as well as their combination, on SGC-7901 apoptosis, the apoptotic morphology of cells was observed under a fluorescence microscope. SGC-7901 cells in the control group grew well and exhibited homogeneous sizes, regular nuclei, smooth nuclear membranes and evenly-distributed chromatin (Fig. 2). Following treatment with DDP or SAL, cellular morphology appeared altered. Cell numbers were reduced, and DNA appeared condensed and near the nuclear membrane. Apoptotic bodies were formed, and the cellular nuclei became more condensed. The combination of DDP and SAL produced more pronounced morphological alterations on SGC-7901 cells compared with the DDP alone and SAL alone groups (Fig. 2).

Effects of SAL and DDP on SGC-701 cell cycle progression. To determine the effects of SAL or DDP alone, as well as their combination, on cell cycle distribution, flow cytometry was used. Following treatment with DDP or SAL for $48 \mathrm{~h}$, the number of SGC-7901 cells in $\mathrm{G}_{0} / \mathrm{G}_{1}$ phase decreased, whereas the number of cells in $\mathrm{S}$ phase increased (Fig. 3A-D). SGC-7901 cells in S phase accounted for 33.52 and $34.57 \%$ of total cells in the DDP- and SAL-treated groups, respectively, which were significantly different compared with the control group (22.43\%; $\mathrm{P}<0.05)$. These results suggested that $\mathrm{SAL}$ and DDP caused S phase arrest in SGC-7901 cells. The cells in $\mathrm{S}$ phase in the SAL and DDP combined treatment group accounted for $57.45 \%$ of the population, which was significantly higher compared with the control, DDP alone and SAL alone groups $(\mathrm{P}<0.05)$.

SAL and DDP induce cellular apoptosis. To determine the effects of SAL or DDP alone, as well as their combination, on SGC-7901 cell apoptosis, apoptotic cells were detected using flow cytometry. Apoptotic rates of SGC-7901 cells were 9.76 and $14.69 \%$ following treatment with DDP and SAL respectively (Fig. 4), and were significantly higher compared with the control group $(2.37 \% ; \mathrm{P}<0.05)$. The apoptotic rate of SGC-7901 cells was $27.79 \%$ following treatment with the combination of DDP and SAL, which was significantly higher compared with the control, DDP alone and SAL alone groups $(\mathrm{P}<0.05)$. These results suggested that SAL and DDP alone, as well as their combination, were able to induce SGC-7901 cell apoptosis, and the combined treatment produced more potent proapoptotic effects.

Effects of SAL and DDP on NF- $\kappa B$ p65 and FasL expression. To investigate the mechanism underlying the proapoptotic effects of SAL and DDP, as well as their combination, immunohistochemistry was performed to assess the expression of NF- $\kappa \mathrm{B}$ p65 and FasL following treatment. The present results demonstrated that $\mathrm{NF}-\kappa \mathrm{B}$ p65 was expressed in control cells, as nuclei were stained dark brown (Fig. 5B). Following treatment with DDP or SAL, NF- $\mathrm{B}$ p65 expression was decreased, as the intensity of nuclear and cytosolic staining appeared reduced (Fig. 5C and D). The combination treatment group had much lower NF- $\mathrm{B}$ p65 expression than those in the control group and the DDP and SAL separate treatment groups. The cell nuclei exhibited decreased brown color and presented some blue color, and part of the cytosol showed light brown color (Fig. 5E).

The expression of FasL in control SGC-7901 cells appeared low, as revealed by the low intensity of brown staining present in the cytosol and cell membrane (Fig. 6B). Following treatment with DDP or SAL, the expression of FasL in the cytosol appeared to be increased, as the intensity of staining increased. SAL-treated gastric cancer cells exhibited higher FasL expression compared with DDP-treated cells, as suggested by the higher intensity of nuclear and cytosolic staining present in SAL-treated cells (Fig. 6C and D). Cells treated with a combination of DDP and SAL exhibited increased FasL staining compared with the control, DDP alone and SAL alone groups, as the intensity of dark brown nuclear and cytosolic staining appeared markedly increased (Fig. 6E).

\section{Discussion}

Gastric cancer is one of the most common malignant tumors in the clinical setting. As an ionophore antibiotic, SAL may contribute to the inhibition of tumor cell proliferation. However, it has previously been reported that SAL may exhibit strong neurotoxic effects (22). DDP is a conventional chemotherapy drug used in clinical practice that exhibits significant antitumor effects. However, it has been reported to be prone to induce drug resistance during the treatment of gastric cancer, which may eventually lead to treatment failure $(4,5)$. The results of the present study suggested that SAL may enhance the susceptibility of SCG-7901 gastric cancer cells to DDP, and the mechanism underlying its effects may involve NF- $\mathrm{B}$ p65 downregulation and FasL upregulation.

$\mathrm{NF}-\kappa \mathrm{B}$ is a nuclear transcription factor that has been implicated in various physiological and pathophysiological processes, such as embryonic development, tissue injury and repair, inflammation, viral infection, tumor development and progression, and in the regulation of apoptosis-related gene expression (23-25). Under physiological conditions, $\mathrm{NF}-\kappa \mathrm{B}$ remains in the cytosol in the form of inactive p65/p50/inhibitor of $\kappa \mathrm{B}(\mathrm{I} \kappa \mathrm{B}-\alpha)$ complexes, and thus its transcriptional actions are suppressed (26). Following stimulation by cytokines, physical and chemical factors, such as X-rays and chemotherapy drugs, and other activators, I $\mathrm{KB}-\alpha$ is phosphorylated and ubiquitinated. As a result, the conformation

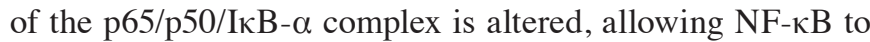
translocate into the nucleus and activate the transcription of target genes $(27,28)$. Previous research has suggested that the suppression of NF- $\mathrm{B}$ may enhance apoptosis mediated by the Fas/FasL signaling pathway (29-31). Fas and FasL are a pair of molecules located on cell membranes, which promote apoptosis via the death receptor pathway. Binding of FasL to Fas can initiate death signaling cascades, leading to cancer cell apoptosis (32-34). Chen et al reported that the expression of Fas/FasL genes may be associated with NF- $\mathrm{BB}$ (29). Travert et al indicated that NF- $\mathrm{BB}$ activation may indirectly inhibit Fas, tumor necrosis factor (TNF) receptor 1 and 

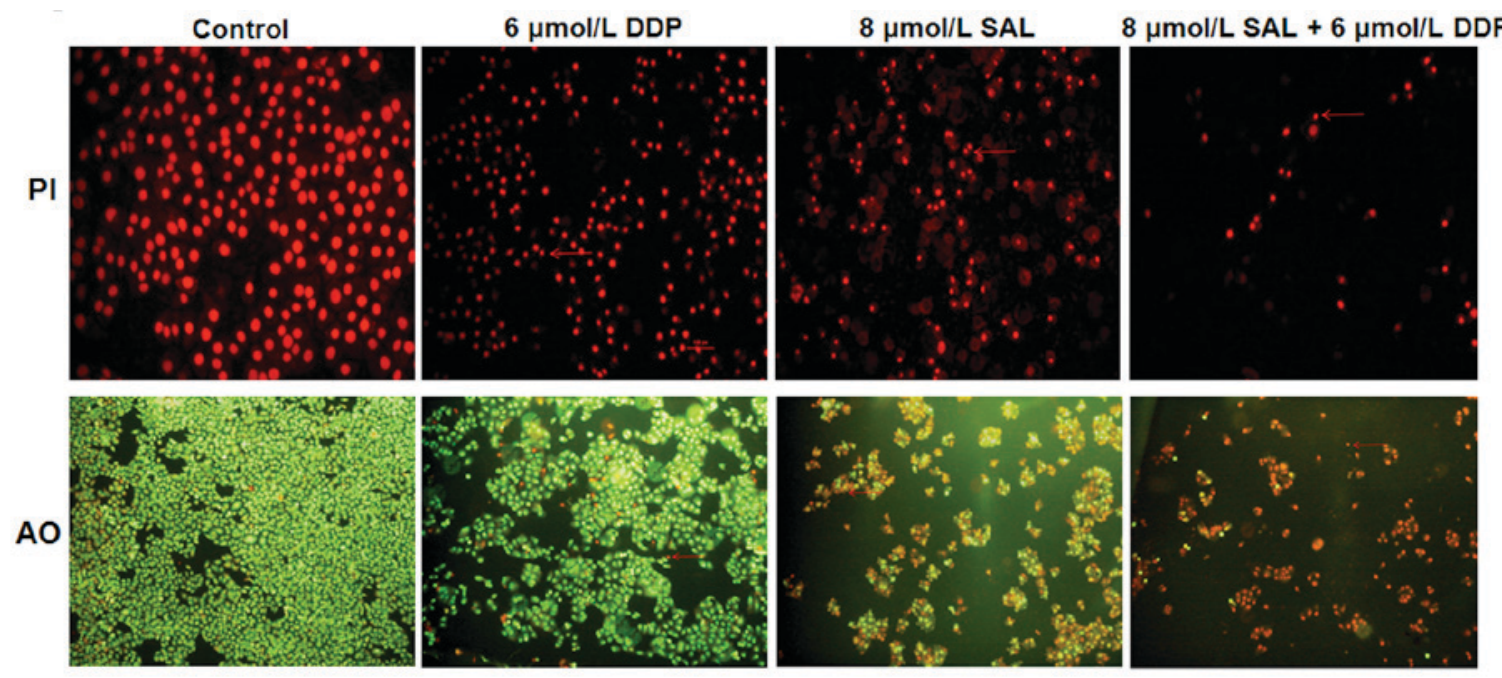

Figure 2. Morphological alterations of apoptotic SGC-7901 cells treated with SAL, DDP or a combination of SAL and DDP were observed under a fluorescence microscope. Cells were treated with $6 \mu \mathrm{mol} / 1 \mathrm{DDP}, 8 \mu \mathrm{mol} / 1 \mathrm{SAL}$, or $8 \mu \mathrm{mol} / 1 \mathrm{SAL}$ combined with $6 \mu \mathrm{mol} / 1 \mathrm{DDP}$ for $48 \mathrm{~h}$. Control cells received no treatment. Subsequently, cells were stained with PI and AO. Arrows indicate condensed DNA and apoptotic bodies. Magnification, x100. SAL, salinomycin; DDP, cisplatin; PI, propidium iodide; $\mathrm{AO}$, acridine orange.

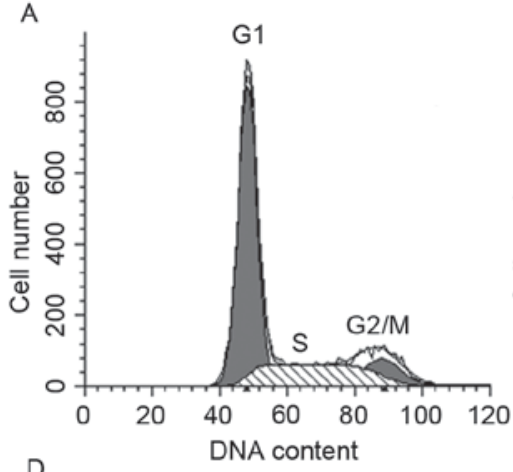

D

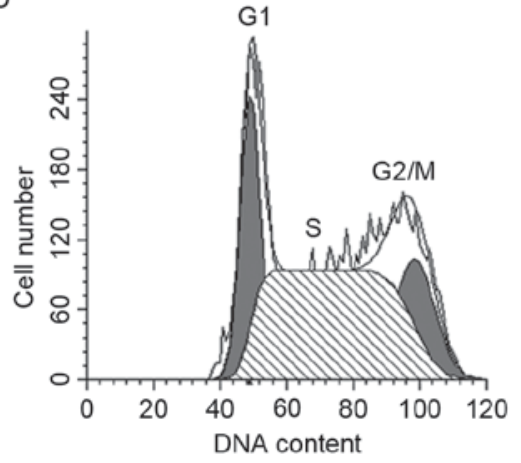

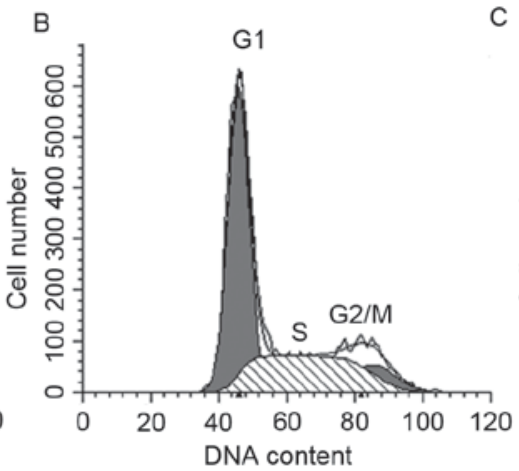

$\mathrm{E}$

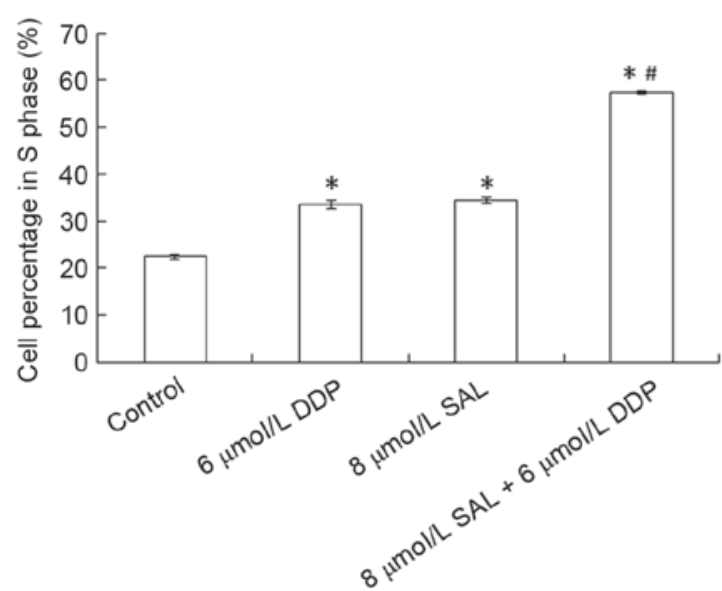

Figure 3. Effects of SAL, DDP or their combination on cell cycle distribution of SGC-7901 cells. Cells were treated with $6 \mu \mathrm{mol} / 1 \mathrm{DDP}, 8 \mu \mathrm{mol} / 1 \mathrm{SAL}$, or $8 \mu \mathrm{mol} / 1 \mathrm{SAL}$ combined with $6 \mu \mathrm{mol} / 1 \mathrm{DDP}$ for $48 \mathrm{~h}$. Control cells received no treatment. Subsequently, flow cytometry was used for cell cycle analysis. Representative and quantitative results are presented. (A) Control cells. (B) Cells treated with $6 \mu \mathrm{mol} / 1 \mathrm{DDP}$. (C) Cells treated with $8 \mu \mathrm{mol} / 1 \mathrm{SAL}$. (D) Cells treated with a combination of $8 \mu \mathrm{mol} / \mathrm{SAL}$ and $6 \mu \mathrm{mol} / \mathrm{l}$ DDP. (E) Percentage of cells in S phase. Data are expressed as the mean \pm standard deviation. ${ }^{*} \mathrm{P}<0.05$ compared with the control group; $\mathrm{P}<0.05$ compared with the DDP or SAL groups. SAL, salinomycin; DDP, cisplatin.

TNF-related apoptosis-inducing ligand, to ultimately promote cellular apoptosis (30). Therefore, since $\mathrm{NF}-\kappa \mathrm{B}$ and FasL may serve a role in the promotion of tumor cell apoptosis (35-39), the present study investigated the implication of $\mathrm{NF}-\kappa \mathrm{B}$ and
FasL in the mechanisms underlying the proapoptotic actions of SAL.

SAL has previously been reported to inhibit the proliferation of breast cancer stem-like cells via an apoptosis-independent 
A

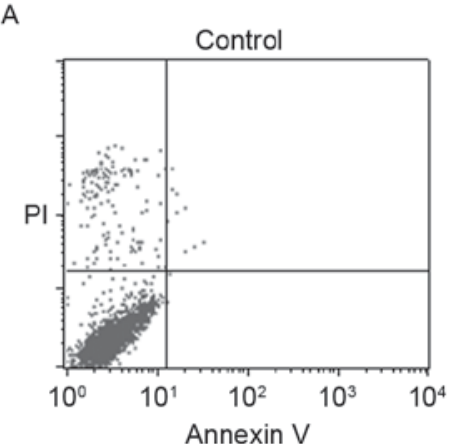

D

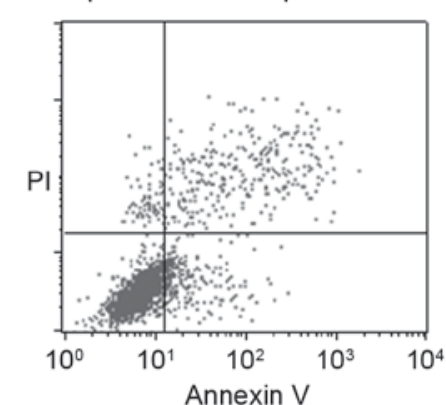

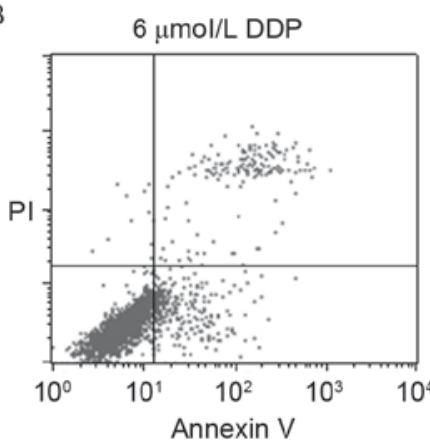
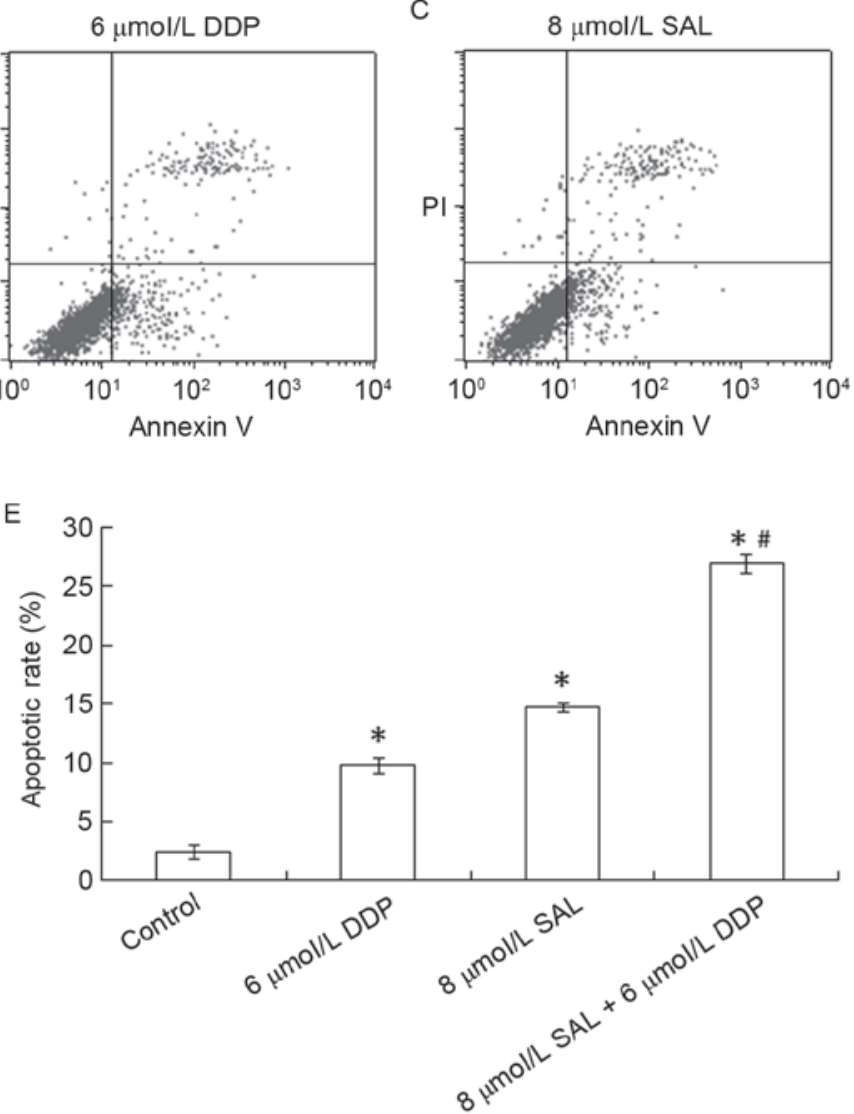

Figure 4. Apoptotic rates of SGC-7901 cells following treatment with SAL, DDP or a combination of SAL and DDP. Cells were treated with $6 \mu \mathrm{mol} / 1$ DDP, $8 \mu \mathrm{mol} / 1 \mathrm{SAL}$, or $8 \mu \mathrm{mol} / 1 \mathrm{SAL}$ combined with $6 \mu \mathrm{mol} / 1 \mathrm{DDP}$ for $48 \mathrm{~h}$. Control cells received no treatment. Subsequently, flow cytometry was used to assess cellular apoptosis. Representative and quantitative results are presented. (A) Control cells. (B) Cells treated with $6 \mu \mathrm{mol} / 1$ DDP. (C) Cells treated with $8 \mu \mathrm{mol} / 1$ SAL. (D) Cells treated with a combination of $8 \mu \mathrm{mol} / \mathrm{SAL}$ and $6 \mu \mathrm{mol} / 1 \mathrm{DDP}$. (E) Apoptotic rate of cells in the various treatment groups. Data are expressed as the mean \pm standard deviation. ${ }^{*} \mathrm{P}<0.05$ compared with the control group; ${ }^{\prime} \mathrm{P}<0.05$ compared with the DDP or SAL groups. SAL, salinomycin; DDP, cisplatin; PI, propidium iodide.

pathway (40). Zhi et al demonstrated that SAL selectively inhibited the proliferation of gastric cancer cells characterized by high aldehyde dehydrogenase activity, which are resistant to 5 -fluorouracil and DDP (21). In the present study, SAL was demonstrated to inhibit the proliferation of gastric cancer cells in a dose- and time-dependent manner. These results are in accordance with the study by Zhi et al (21), as they demonstrated the cytotoxic effects of SAL on gastric cancer cells. Furthermore, the present study suggested that the combination of SAL and DDP may possess more potent cytotoxic potential compared with treatment with SAL or DDP alone. The addition of SAL appeared to enhance the susceptibility of gastric cancer cells to DDP. Treatment with SAL or DDP alone, as well as their combination, was revealed to alter cellular morphology, and combined treatment exhibited stronger effects compared with separate treatments. PI and AO staining, and flow cytometry demonstrated that the apoptotic rate of cells treated with the combination of SAL and DDP was markedly higher compared with the control, DDP alone and SAL alone groups. These results suggested that SAL and DDP may be able to synergistically induce gastric cancer cell apoptosis. These results are consistent with the study by Liu et al, which reported that SAL alone and in combination with vincristine induced apoptosis of Jurkat cancer cells (41).
The present study demonstrated that SAL alone and in combination with DDP could alter cell cycle distribution and prolong the $\mathrm{S}$ phase, and combined treatment exhibited stronger effects compared with treatment with SAL or DDP alone. These results suggested that the mechanisms underlying the inhibitory effects of SAL and DDP may involve interference in DNA synthesis and replication in cancer cells. Immunocytochemistry was used to further investigate the mechanisms underlying the proapoptotic actions of SAL and DDP. The present results revealed that SAL and DDP inhibited the translocation of NF- $\kappa \mathrm{B}$ p65 into the nuclei of cancer cells. The combination of SAL and DDP markedly downregulated the expression of NF- $\mathrm{kB}$ p65 and upregulated the expression of FasL. These results suggested that SAL and DDP may induce cancer cell apoptosis via inhibiting the activation of NF- $\mathrm{KB}$ p 65 and promoting the activation of Fas/FasL pathways, consistent with previous findings (29-31). Combination of the drugs enhanced the proapoptotic actions of DDP on SGC-7901 cells. In accordance with the present results, Parajuli et al reported that SAL inhibited the nuclear translocation of NF- $\mathrm{kB}(42)$.

In conclusion, the present study demonstrated that the novel anticancer agent SAL inhibited gastric cancer cell proliferation, alone or in combination with DDP, and 
A

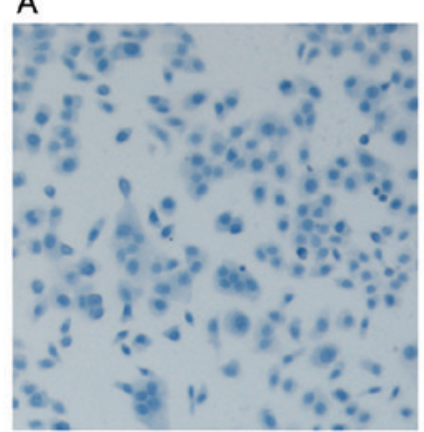

D

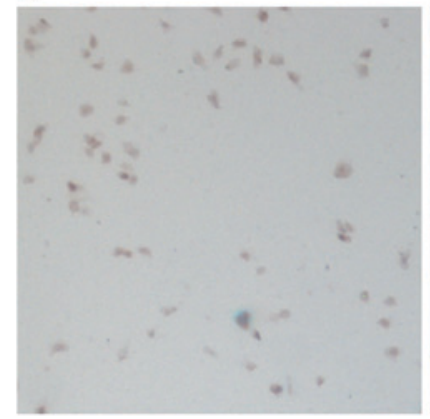

B

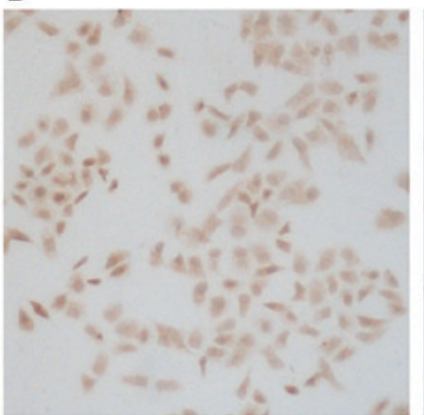

$E$

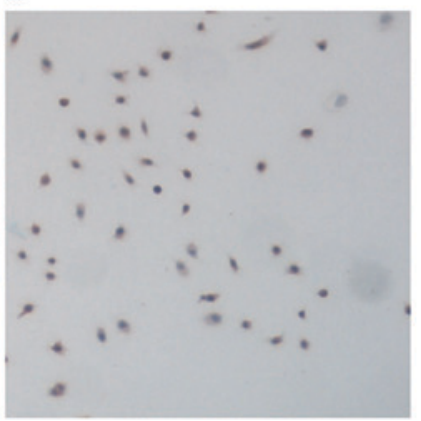

C

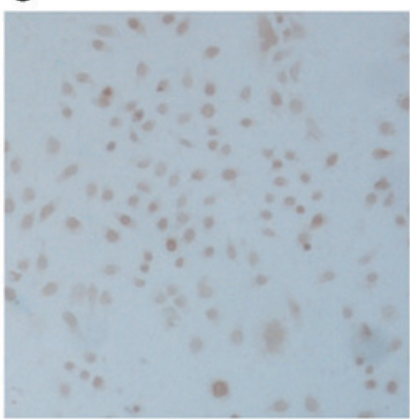

Figure 5. NF-kB p65 expression in SGC-7901 cells following treatment with SAL, DDP or a combination of SAL and DDP for 48 h. (A) As a negative control, untreated cells were incubated with 1X PBS, instead of primary antibody. (B-E) Cells were incubated with anti-NF-kB p65 primary antibody. (B) Control cells received no treatment. (C) Cells were treated with $6 \mu \mathrm{mol} / 1$ DDP. (D) Cells were treated with $8 \mu \mathrm{mol} / 1 \mathrm{SAL}$. (E) Cells were treated with a combination of $8 \mu \mathrm{mol} / \mathrm{SAL}$ and $6 \mu \mathrm{mol} / 1 \mathrm{DDP}$. Magnification, x100. NF, nuclear factor; SAL, salinomycin; DDP, cisplatin.

A

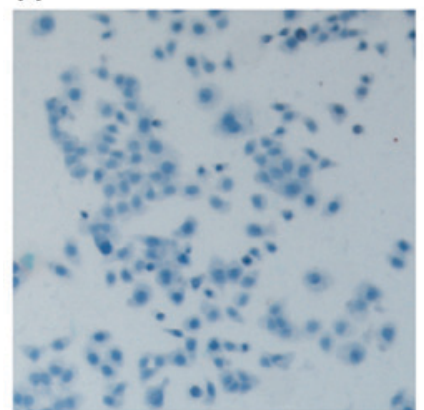

D

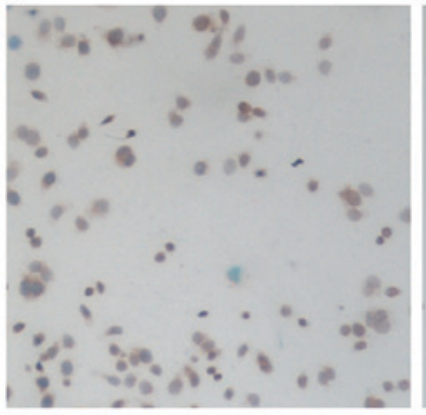

B

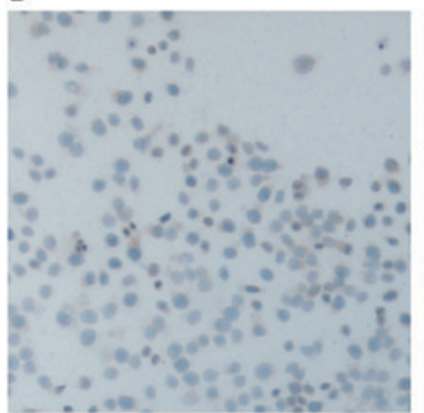

E

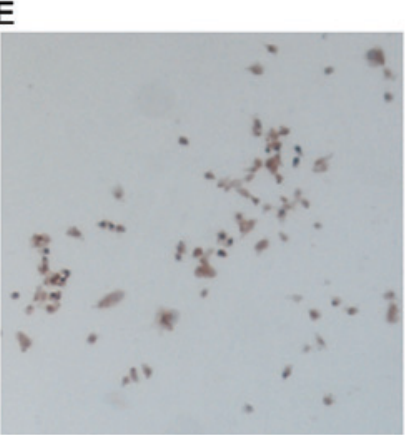

C

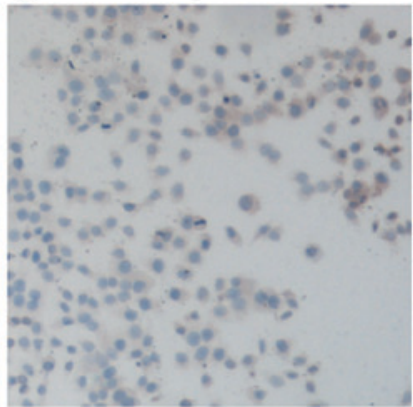

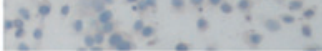

Figure 6. FasL expression in SGC-7901 cells following treatment with SAL, DDP or a combination of SAL and DDP for $48 \mathrm{~h}$. (A) As a negative control, untreated cells were incubated with $1 \mathrm{X}$ PBS, instead of primary antibody. (B-E) Cells were incubated with anti-FasL primary antibody. (B) Control cells received no treatment. (C) Cells were treated with $6 \mu \mathrm{mol} / 1$ DDP. (D) Cells were treated with $8 \mu \mathrm{mol} / 1 \mathrm{SAL}$. (E) Cells were treated with a combination of $8 \mu \mathrm{mol} / \mathrm{SAL}$ and $6 \mu \mathrm{mol} / 1 \mathrm{DDP}$. Magnification, $\mathrm{x} 100$. FasL, Fas protein ligand; SAL, salinomycin; DDP, cisplatin.

induced cellular apoptosis. The present results suggested that the mechanisms underlying its actions may involve upregulation of FasL and downregulation of NF- $\mathrm{kB}$ p65 expression.

\section{Acknowledgements}

The present study was supported by the National Science Foundation (grant no. 81470140) and the Health Science and 
research project of Shaanxi Province (grant no. 2014D31).

\section{References}

1. Chen W, Zhang R, Zhang S, Zhao P, Li G, Wu L and He J: Report of incidence and mortality in China cancer registries, 2009. Chin J Cancer Res 25: 10-21, 2013

2. Lenz HJ, Lee FC, Haller DG, Singh D, Benson AB III, Strumberg D, Yanagihara R, Yao JC, Phan AT and Ajani JA Extended safety and efficacy data on S-1 plus cisplatin in patients with untreated, advanced gastric carcinoma in a multicenter phase II study. Cancer 109: 33-40, 2007.

3. Li G, Yang F, Gu S, Li Z and Xue M: MicroRNA-101 induces apoptosis in cisplatin-resistant gastric cancer cells by targeting VEGF-C. Mol Med Rep 13: 572-578, 2016.

4. Chen DD, Feng LC, Ye R, He YQ and Wang YD: miR-29b reduces cisplatin resistance of gastric cancer cell by targeting PI3K/Akt pathway. Zhongguo Yi Xue Ke Xue Yuan Xue Bao 37 514-519, 2015 (In Chinese).

5. Zhou X, Jin W, Jia H, Yan J and Zhang G: MiR-223 promotes the cisplatin resistance of human gastric cancer cells via regulating cell cycle by targeting FBXW7. J Exp Clin Cancer Res 34: 28, 2015.

6. Huczyński A: Polyether ionophores-promising bioactive molecules for cancer therapy. Bioorg Med Chem Lett 22: 7002-7010, 2012.

7. Miyazaki Y, Shibuya M, Sugawara H, Kawaguchi O and Hirsoe C: Salinomycin, a new polyether antibiotic. J Antibiot (Tokyo) 27: 814-821, 1974.

8. Daugschies A, Gässlein U and Rommel M: Comparative efficacy of anticoccidials under the conditions of commercial broiler production and in battery trials. Vet Parasitol 76: 163-171, 1998.

9. Danforth HD, Ruff MD, Reid WM and Miller RL: Anticoccidial activity of salinomycin in battery raised broiler chickens. Poult Sci 56: 926-932, 1977.

10. Mahmoudi N, de Julián-Ortiz JV, Ciceron L, Gálvez J, Mazier D, Danis M, Derouin F and García-Domenech R: Identification of new antimalarial drugs by linear discriminant analysis and topological virtual screening. J Antimicrob Chemother 57: 489-497, 2006.

11. Gupta PB, Onder TT, Jiang G, Tao K, Kuperwasser C, Weinberg RA and Lander ES: Identification of selective inhibitors of cancer stem cells by high-throughput screening. Cell 138: 645-659, 2009

12. Naujokat C, Fuchs D and Opelz G: Salinomycin in cancer: A new mission for an old agent. Mol Med Rep 3: 555-559, 2010.

13. Kopp F, Hermawan A, Oak PS, Ulaganathan VK, Herrmann A, Elnikhely N, Thakur C, Xiao Z, Knyazev P, Ataseven B, et al: Sequential salinomycin treatment results in resistance formation through clonal selection of epithelial-like tumor cells. Transl Oncol 7: 702-711, 2014.

14. Kim JH, Chae M, Kim WK, Kim YJ, Kang HS, Kim HS and Yoon S: Salinomycin sensitizes cancer cells to the effects of doxorubicin and etoposide treatment by increasing DNA damage and reducing p21 protein. Br J Pharmacol 162: 773-784, 2011.

15. Xiao Z, Sperl B, Ullrich A and Knyazev P: Metformin and salinomycin as the best combination for the eradication of NSCLC monolayer cellsand their alveospheres (cancer stem cells) irrespective of EGFR, KRAS, EML4/ALK and LKB1 status. Oncotarget 5: 12877-12890, 2014.

16. Antoszczak M, Popiel K, Stefańska J, Wietrzyk J, Maj E, Janczak J, Michalska G, Brzezinski B and Huczyński A: Synthesis, cytotoxicity and antibacterial activity of new esters of polyether antibiotic - salinomycin. Eur J Med Chem 76: 435-444, 2014.

17. Kopp F, Hermawan A, Oak PS, Herrmann A, Wagner E and Roidl A: Salinomycin treatment reduces metastatic tumor burden by hampering cancer cell migration. Mol Cancer 13: 16, 2014.

18. Huczynski A: Salinomycin: A new cancer drug candidate. Chem Biol Drug Des 79: 235-238, 2012.

19. Moretti M, Bennett J, Tornatore L, Thotakura AK and Franzoso G: Cancer: NF- $\mathrm{BB}$ regulates energy metabolism. Int J Biochem Cell Biol 44: 2238-2243, 2012.

20. Ni M, Xiong M, Zhang X, Cai G, Chen H, Zeng Q and Yu Z: Poly (lactic-co-glycolic acid) nanoparticles conjugated with CD133 aptamers for targeted salinomycin delivery to CD133+ osteosarcoma cancer stem cells. Int J Nanomedicine 10: 2537-2554, 2015.

21. Zhi QM, Chen XH, Ji J, Zhang JN, Li JF, Cai Q, Liu BY, Gu QL, Zhu ZG and Yu YY: Salinomycin can effectively kill ALDH (high) stem-like cells on gastric cancer. Biomed Pharmacother 65 509-515, 2011.
22. Song SP, Zhang XG, Wang M, et al: Change and significance of serum creatine kinase and its isoenzyme in salinomycin poisoning patients. Zhong Guo Wei Sheng Jian Yan Za Zhi 21: 28-29, 2011

23. Cai Z, Tchou-wong KM and Rom WN: NF-kappaB in lung tumorigenesis. Cancers (Basel) 3: 4258-4268, 2011.

24. Hayden MS and Ghosh S: Shared principles in NF-kappaB signaling. Cell 132: 344-362, 2008.

25. Varfolomeev E, Goncharov T, Maecker H,Zobel K, Kömüves LG, Deshayes K and Vucic D: Cellular inhibitors of apoptosis are global regulators of NF- $\kappa \mathrm{B}$ and MAPK activation by members of the TNF family of receptors. Sic Signal 5: ra22, 2012.

26. Majdalawieh A and Ro HS: Regulation of IkappaBalpha function and NF-kappaB signaling: AEBP1 is a novel proinflammatory mediator in macrophages. Mediators Inflamm 2010: 823821, 2010.

27. Lee HJ, Seo HS, Kim GJ, Jeon CY, Park JH, Jang BH, Park SJ, Shin YC and Ko SG: Houttuynia cordata Thunb inhibits the production of pro-inflammatory cytokines through inhibition of the NFאB signaling pathway in HMC-1 human mast cells. Mol Med Rep 8: 731-736, 2013.

28. Ferreiro DU and Komives EA: Molecular mechanisms of system control of NF-kappaB signaling by IkappaBalpha. Biochemistry 49: 1560-1567, 2010.

29. Chen S, Dong Y, Xu C, Jiang L, Chen Y, Jiang C, Hou W and Li W: Involvement of a chromatin modifier in response to mono-(2-ethylhexyl) phthalate (MEHP)-induced Sertoli cell injury: Probably an indirect action via the regulation of NF- $\kappa \mathrm{B} / \mathrm{FasL}$ circuitry. Biochem Biophys Res Commun 440: 749-755, 2013.

30. Travert M, Ame-Thomas P, Pangault C, Morizot A, Micheau O, Semana G, Lamy T, Fest T, Tarte K and Guillaudeux T: CD40 ligand protects from TRAIL-induced apoptosis in follicular lymphomas through NF-kappaB activation and up-regulation of c-FLIP and Bcl-xL. J Immunol 181: 1001-1111, 2008.

31. Wang L, Zhao S, Wang HX and Zou P: Inhibition of NF-kappa B can enhance Fas-mediated apoptosis in leukemia cell line HL-60. Front Med China 4: 323-328, 2010.

32. Strasser A, Jost PJ and Nagata S: The many roles of FAS receptor sig-naling in the immune system. Immunity 30: 180-192, 2009.

33. Mahmood Z and Shukla Y: Death receptors: Targets for cancer therapy. Exp Cell Res 316: 887-899, 2010.

34. Chen L, Park SM, Tumanov AV, Hau A, Sawada K, Feig C, Turner JR, Fu YX, Romero IL, Lengyel E and Peter ME: CD95 promotes tumour growth. Nature 465: 492-496, 2010.

35. Kong FC, Zhang JQ, Zeng C, Chen WL, Ren WX, Yan GX, Wang HX, Li QB and Chen ZC: Inhibitory effects of parthenolide on the activity of NF- $\mathrm{KB}$ in multiple myeloma via targeting TRAF6. J Huazhong Univ Sci Technolog Med Sci 35: 343-349, 2015.

36. Diab S, Fidanzi C, Léger DY, Ghezali L, Millot M, Martin F, Azar R, Esseily F, Saab A, Sol V, et al: Berberis libanotica extract targets NF- $\kappa \mathrm{B} / \mathrm{COX}-2$, PI3K/Akt and mitochondrial/caspase signalling to induce human erythroleukemia cell apoptosis. Int J Oncol 47: 220-230, 2015.

37. Gmeiner WH, Jennings-Gee J, Stuart $\mathrm{CH}$ and Pardee TS: Thymineless death in F10-treated AML cells occurs via lipid raft depletion andFas/FasL co-localization in the plasma membrane with activation of the extrinsic apoptotic pathway. Leuk Res 39: 229-235, 2015.

38. Liu W, Lin YT, Yan XL, Ding YL, Wu YL, Chen WN and Lin X: Hepatitis B virus core protein inhibits Fas-mediated apoptosis of hepatoma cells via regulation of $\mathrm{mFas} / \mathrm{FasL}$ and sFas expression. FASEB J 29: 1113-1123, 2015.

39. Li L, Yao YC, Fang SH, Ma CQ, Cen Y, Xu ZM, Dai ZY, Li C, Li S, Zhang T, et al: Pigment epithelial-derived factor (PEDF)-triggered lung cancer cell apoptosis relies on p53 protein-driven Fas ligand (Fas-L) up-regulation and Fas protein cell surface translocation. J Biol Chem 289: 30785-30799, 2014.

40. An H, Kim JY, Lee N, Cho Y, Oh E and Seo JH: Salinomycin possesses anti-tumor activity and inhibits breast cancer stem-like cells via an apoptosis-independent pathway. Biochem Biophys Res Commun 466: 696-703, 2015.

41. Liu PP, Zhu JC, Liu GX, Shui CX and Li XM: Salinomycin enhances the apoptosis of T-cell acute lymphoblastic leukemia cell line jurkat cells induced by vincristine. Zhongguo Shi Yan Xue Ye Xue Za Zhi 23: 653-657, 2015 (In Chinese).

42. Parajuli B, Shin SJ, Kwon SH, Cha SD, Chung R, Park WJ, Lee HG and Cho CH: Salinomycin induces apoptosis via death receptor-5 up-regulation in cisplatin-resistant ovarian cancer cells. Anticancer Res 33: 1457-1462, 2013. 